\title{
Public Diplomacy as Co-constructed Discourses of Engagement
}

Dr. Alina Dolea

Public diplomacy has become today more about public communication, global public issues and engagement with various publics across the world than ever before. This chapter reviews briefly the reconceptualization of engagement within the field of public diplomacy over time and argues that the recent critical turn from scholars within and, mostly, from outside the field can open new avenues for study and practice. Building on a sociological perspective (Castells, 2008; Wiseman, 2015) and on the concept of dialogic engagement (Taylor \& Kent, 2014) public diplomacy is conceptualized as constructed discourses of engagement: a dynamic dialogic process and, at the same time, an outcome of the interactions and negotiations between state and non-state actors, with different power positions and agendas, who compete and influence each other, yet contribute to the co-construction of a public sphere. Consequently, critical discourse analysis is proposed as a framework for analyzing public diplomacy as discourses of engagement, discourse that constitutes social practice and is constituted by it. This theoretical discussion is illustrated with a case study from Romania, the campaign "Why don't you come over?" of the Romanian newspaper Gandul.info and GMP communication group to show different levels of engagement embedded in the concept of public diplomacy as constructed discourses of engagement: participation, interaction, and co-creation. The analysis reveals how a non-state actor engaged in a public diplomacy topic, created a platform for online engagement and empowered Romanian citizens to engage in a debate about themselves: thus, they co-created discourses about their country that ultimately reached the public agenda and produced multiplication communication effects offline (e.g. a media company offered free outdoor advertising in bus-shelters and hotels; a pub displayed the posters; British journalists and politicians visited Romania).

\section{Current Public Diplomacy is Engagement}


The concept of engagement has gradually become a central tenet in public diplomacy. Moreover, many argue that the new public diplomacy is actually engagement:

Diplomacy is the management of foreign policy though an official engagement with a foreign government. Public diplomacy (PD) is the management of foreign policy through a government engagement with a foreign public. The New Public Diplomacy (NPD) primarily describes people to people engagement on common or conflicting national and global interests. (Gilboa, 2015, p.1)

Gilboa's definitions embody the major shifts that occurred overtime in public diplomacy: they show engagement has been part of the conversation and definitions of public diplomacy from the beginning, but somehow the concept ended up on the margins. Engagement as a concept was under developed because scholars have focused mainly on the state as the main actor in public diplomacy and its aim to manage the environment. In this approach, public diplomacy was studied mainly in terms of improving the practices in order for objectives to be achieved. In the quest for efficiency, the scholarship in public diplomacy lacked a discussion on what exactly engagement entails because the entire communication process was understood as a uni-directional: "direct communication with foreign peoples, with the aim of affecting their thinking and, ultimately, that of their governments" (Malone, 1985, p. 199); "a government's process of communication with foreign publics in an attempt to bring about understanding for its nation's ideas and ideals, its institutions and culture, as well as its national goals and policies" (Tuch, 1990, p.3). Thus, public diplomacy has been conceptualized as a process in which governments have the central role, aim to control both the process and the environment and they often achieve that because they are in a position of power.

The limits of this state-centric perspective in public diplomacy have come to be realized with the rethinking of the practice and the conceptualization of the new public diplomacy after 9/11 (Melissen, 2005). The new international environment, the multitude of actors involved in public diplomacy and the rapidly changing technologies have prompted engagement as being central in effective public diplomacy (as shown, among other, by Cull, 2009). While the relationship building approach redefines the influence approach in the previous state-centric perspective, engagement was still insufficiently explored. This is mainly due to the domination of the functionalist paradigm in public diplomacy that continues to privilege the position and the 
perspective of the state in its relationship with other actors. Indeed, most studies are meant to identify better instruments for crafting messages and to furnish solutions for improving the practice in general, drawing heavily on the (new) roles of practitioners.

In fact, until recently, the public diplomacy scholarship was embedded in international relations. This led to certain insularity and single disciplinary perspectives in the discussion of both the practice and theory of public diplomacy, even though techniques of nation branding or public relations had started to be incorporated in practice. A slow conceptual evolution towards approaches from other disciplines has gradually taken place: "by focusing on global engagement [...], public diplomacy research has gained much attention from international relations, mass communications, and political scientists alike" (Golan, 2013, p. 1251). The relationship approach in public diplomacy praised among others by Fitzpatrick (2007, 2010) and developed by Zaharna, Arsenault, and Fisher (2013) was inspired by the public relations scholarship and its focus on relationship building. The cross-fertilization of public diplomacy and public relations has resulted in the exploration of new and different perspectives, thus advancing the field.

In addition, public diplomacy itself started not only to consolidate its public dimension, but also to gain a more pronounced social relevance. It went from being somehow isolated within the abstract field of international relations and diplomacy where international treaties are signed (but have little relevance for people at large) to becoming of interest for society and being articulated by it. As a result, besides the traditional studies on media diplomacy (Gilboa, 1998) or cultural diplomacy (Mark, 2009), there are new streams of research discussing non-state actors diplomacy (Langhorne, 2005), corporate diplomacy (Henisz, 2014; Ordeix-Rigo \& Duarte, 2009;), digital diplomacy or public diplomacy 2.0 (Comor \& Bean, 2012; Cull, 2013). This reflects the rapidly changing and developing nature of the public diplomacy practices and, at the same time, the evolution in thinking about public diplomacy.

Yet, despite the steps forward made by interdisciplinary studies, there is still a prevalence of a functionalist and rather normative understanding of country promotion practices, in general, and public diplomacy, as well (Dolea, 2015a). In this context, the stream of critical research that has been coagulating in public diplomacy (Castells, 2008; Comor \& Bean, 2013; Der Derian, 2009; Dutta Bergman, 2006; Hayden, 2012; Lord \& Lynch, 2010; Pamment, 2012; Snow, 2009) has, in my opinion, the greatest potential to contribute to the further development of the field. At 
the same time, the emergent critical thinking in public relations (L'Etang, 2009) and in nation branding (e.g. Aronczyk, 2008; Kaneva 2009, 2011; Volcic, 2008) offers new conceptual, theoretical and methodological avenues to explore when critically discuss public diplomacy. Critical thinking makes it possible to discuss the narratives and a rhetoric of public diplomacy which "is the attempt to discern the stable structures of influence emergent within networks or, barring that, to at best anticipate how the acts of communication function influentially as symbols signifying credibility within networks" (Hayden, 2013, p. 214). And to reflect on public diplomacy using, for example, the network society theory: "diplomatic and governance actors are categorized in trans-governmental and polylateral networks. Civil society and private sector actors are categorized in cosmopolitan and private governance networks" (Gregory 2015, p. 1). More importantly, the discussion about public diplomacy starts to include more and more aspects related to inequality and power issues from a critical perspective:

..public diplomacy activities are rarely the product of rational choices about communication options ... rather, questions of public diplomacy and evaluation practices are bound together in complex organizational and power structures that generate pragmatic responses both to the "problem of influence" and the reporting of results (Pamment, 2014, p. 50).

These new perspectives, generally referred to as "the critical turn" in public diplomacy scholarship, actually question the limits of conceptualizing engagement in a positivist approach. that reduces public diplomacy to a mere "planned process, based on a carefully researched understanding of the audience and of its interests, couched in language calibrated to engage the audience in the intended manner, using the best one- or two-way method of engagement" (Lord \& Lynch, 2010, p. 11). On the contrary, "moving engagement away from its predominantly marketing and public relations orientations and towards, instead, a more ethically and democratically principled approach" (Comor \& Bean, 2013, p. 204), it is possible to understand public diplomacy as a more complex process of communication that requires constant interaction, dialogue and (re)adaptation of one's goals in relation with others. Thus, the very focus in public diplomacy shifts from the powerful state as the main actor that has the control over this communication process towards other actors and society that also contribute to and influence this process. 
In other words, engagement in public diplomacy is not the aim in itself, as a mere benchmark to be used in the evaluation of public diplomacy programs and activities. This perspective is useful, but not sufficient: there is a need for efficient strategic planning and constant professionalization in public diplomacy; but, the current rapidly changing contexts at global, regional and national levels require also an increased reflection on the role of public diplomacy and of the public diplomat in society. Thus, engagement with various publics can not be seen only as an outcome of carefully and meticulously crafted process of strategic communication, but rather engagement is part of the process itself.

Public diplomacy has become "social practice" as correctly pointed out by Wiseman (2015). Therefore, it is time to go beyond the one- and two-way models of communication and engagement in public diplomacy in order to reflect on this social practice, mainly on its articulation, impact, and contribution to society. The dominant approaches in public diplomacy have focused on public diplomacy's role within and for governments, within and for the world of international politics. With the current global issues affecting everyone and the increased lack of trusts in governments and institutions to address these issues, a socially centered understanding and practice of public diplomacy might be more needed for the challenges of the $21^{\text {st }}$ century. Moreover, this could contribute to theory building in public diplomacy as it brings new angles and approaches.

\section{Conceptualizing Public Diplomacy as Constructed Discourses of Engagement}

In line with the critical turn in public diplomacy, I argue that public diplomacy is not engagement per se, but a set of discourses of engagement. As such, these discourses are different and compete with each other in a neoliberal world where various actors (e.g. states, nongovernmental actors, corporations) coexist, interact and establish relationships. Furthermore, these discourses of engagement are placed on a global public sphere:

space of debate on public affairs ... shifted from the national to the global and is increasingly constructed around global communication networks [...]"the goal of public diplomacy, in contrast to government diplomacy, is not to assert power or to negotiate a rearrangement of power relationships... it is to induce a communication space in which a new, common language could emerge as a precondition for diplomacy, so that when the 
time for diplomacy comes, it reflects not only interests and power making but also meaning and sharing (Castells, 2008, p. 78).

In Castells' view of public diplomacy, the state has lost its role as a central actor and public diplomacy itself is not an instrument to be used by actors to achieve certain goals. Public diplomacy is seen as having a greater function in society, contributing to the establishment of a communication space where various actors interact, "in which diverse voices can be heard in spite of their various origins, distinct values, and often contradictory interests" (Castells, 2008, p. 91). Understanding public diplomacy as discourse makes it possible to focus on the actual interplay and interactions between actors, without the a priori focus on an actor's goals and its needs of efficiency.

The flourishing scholarship on public relations as dialogue (Kent \& Taylor, 2002; Heath, Toth \& Waymer, 2009) and more recently on engagement and dialogic engagement (Johnston, 2014; Taylor \& Kent, 2014) is particularly useful in analyzing public diplomacy as constructed discourses of engagement. Recent scholarship brings forward the interaction, the conditions of production, the various contexts, processes and outcomes of public diplomacy and its broader impact and role in society. Thus, it is possible to distinguish between different levels of engagement embedded in the concept of public diplomacy as discourses of engagement: participation (actors engaging in the dynamic dialogic process), interaction (actors interact and mutually influence each other), co-creation (actors trying to impose certain discourses that are ultimately co-created).

In this conceptualization, public diplomacy overcomes the age of normative approaches and "how to" practices and enters into a new age of asking questions, investigating various angles and perspectives, looking at the complexity of the society and wondering which approaches can explain better the current phenomenon. Public diplomacy is no more state centered. It has become society - centered, acknowledging the existence of various actors and messages and an ongoing, dynamic process of dialogue and agreement to shared meanings.

Furthermore, I argue that for the analysis of public diplomacy as discourses of engagement an appropriate framework is the one offered by critical discourse analysis (CDA), an interdisciplinary approach that sees language and text as social practice and is home to various 
directions of research. A CDA direction studies "ideologically biased discourses, and the ways these polarize the representation of us (ingroups) and them (outgroups) [...] strategy of 'positive self-presentation and negative other presentation"' (van Dijk, 2001, p. 103). This perspective allows for deeper analyses of public diplomacy as a discourse about countries in terms of "us" (ingroups) versus "them" (outgroups). It is thus possible to investigate the representations and symbols strategically used and mobilized by countries in their public diplomacy, but also how these reflect certain positions, interactions and evolutions between them overtime (in longitudinal studies).

Another CDA direction looks at "a dialectical relationship between particular discursive events and the situations, institutions and social structures in which they are embedded: [...] the situational, institutional and social contexts shape and affect discourses; [...] discourses influence social and political reality" (De Cillia, Reisigl \& Wodak, 1999, p.157). This direction highlights the importance of different internal contexts and conditions in which discourses are produced, shaped or affected and how this is not a static, but a dynamic, changing process. It brings to the front the tensions taking place between and within state institutions: the actions and programs of a state are usually seen as reflecting the public diplomacy approach of that state. It is thus overlooked that different institutions within the same government might have different visions and even compete to impose a dominant vision at times. Moreover, when the vision on public diplomacy changes within institutions, therefore it is possible to analyze the constant internal (re)construction of public diplomacy.

Finally, a new direction in CDA looks particularly at the key role of media considered by Fairclough (2001) "a site of power, of struggle" and also as a site where language is apparently transparent, illustrating the mediating and constructing role of the media. A similar idea is expressed by Wodak (2001): "In texts discursive differences are negotiated; they are governed by differences in power which are themselves in part encoded in and determined by discourse and by genre" (p. 11). This research direction would be useful in critically discussing the role of media in public diplomacy: while the mediation of public diplomacy is not new in the schorlarly literature, yet new critical perspectives can be brought into the old discussions. Moreover, with the social media advent and the emergence of a critique of social media (Fuchs, 2014), such approaches are all the more important as they contribute to a more liquid, dynamic 
underdtanding and evaluation of public diplomacy beyond quantitative methodologies (number of articles, frames, number of posts, likes, comments or shares, etc)

Conceptualizing public diplomacy as discourses of engagement, it is considered that discourses are constructed and reconstructed by actors, in time, through mutual engagement (e.g. the constant interaction and negotiation) of various social actors: they engage in dialogue and debate trying to impose their own definitions and interpretations, certain significations and symbols, and even manipulate meanings in order to temporarily impose frames. This approach allows the contextualization of public diplomacy within a variety of networks, at different social levels (micro, meso, macro) and moments in time. More importantly, it places the discussion about public diplomacy within the global public sphere where distinct and diverging agendas interact.

\section{Public Diplomacy as Co-constructed Discourses of Engagement: A Case Study from Romania}

Romania, a post-communist country in South-Eastern Europe, has undergone a constant process of re-appearing on the world's map, after the anti-communist revolution in 1989. As compared to the other communist countries in Europe, Romania experienced one of the harshest forms of Communism (e.g. extreme food rationing, persecution of intellectuals and opponents, constant surveillance of population to report on critics of the regime, and demolition of old historic buildings). Above all, there was also the international isolation of the country. Therefore, after 1989 the idea that Romania was unknown and had a bad image was recurrent in the public discourses, becoming one of the mainstays on the public agenda in Romania. Consequently, the Romanian Government was questioned about its initiatives to address that and pressured to promote the country more aggressively: the idea of launching a nation branding strategy was also recurrent. Ultimately, between 1996 and 2010, there were several initiatives, projects and campaigns to communicate and position Romania on the international map, but each endeavor of the state ended up being considered a failure due to suspicions of corruption and money laundering, plagiarism of logo, or of being instrumentalized by ministers in office for internal political gains (see Dolea, 2015b for an in-depth discussion on the historicity of these practices). All these initiatives generated heated media and public debates which ultimately turned the topic 
of Romania's country image and promotion abroad into a public issue: an issue that is of interest for the entire society, not only for the experts in communication or government agencies.

Communication campaigns are thus frequently used tactics in public diplomacy, by both state and not-state actors. The campaign "Why don't you come over" of a non-state actor was chosen in order to illustrate the theoretical discussion on engagement and public diplomacy, as well as the use of a critical discourse analysis approach. The campaign was initiated by the Romanian online newspaper gandul.info, carried out by GMP Advertising and Webstyler and, in terms of impact and rate of engagement, is considered the most successful image campaign for post-communist Romania. Paradoxically, it was a non-state actor's initiative, it employed almost no budget, yet it managed to get extensive international coverage (e.g. Reuters, Time Magazine), hundreds of thousands of Romanians engaged and it was internationally recognized and awarded (double finalist at Cannes Lions 2013, Grand Prix in Digital Campaigns in Golden Drum, Grand Prix in Eurobest in PR; the most awarded campaign in Romanian ADC Awards, Romanian PR Awards and Internetics). To understand its success and analyze it, the following structure of discussion is proposed: (1) a brief introduction on the European context that led to the emergence of the campaign; (2) an overview of the specific Romanian post-communist context; (3) the presentation of the campaign; (4) a CDA analysis of the campaign itself. However, the overall discussion is placed within different national contexts, takes into account the historicity of practices and discourses on the topic and seeks to reflect how actors, contexts and discourses interact and influence each other in the "Why don't you come over" campaign.

Methodologically, the case study builds on previous analysis of how the topic of country image became a public issue in Romania (Dolea, 2015a, 2015b), on a set of materials about the campaign provided by the GMP communication group (interviews with Romanian and foreign journalists, internal documents and evaluations of the campaign, the posters used in the campaign) as well as on media articles of the Guardian and Gandul from January 2013 about the campaign. These artifacts are used to present a historical documentary reconstitution of the campaign. The Critical Discourse Analysis was applied to the posters created by the communication group (18 posters) and Gandul readers (a total of 5 posters).

\section{The National Contexts}

The British context. On January 28 ${ }^{\text {th }}, 2013$ the Guardian (Syal, 2013) published an article claiming the British Government was planning a campaign to discourage potential immigrants 
from Romania and Bulgaria to come to Britain. Titled "You won't like it here!", the campaign would focus on highlighting why Britain is unattractive to migrants: it rains, there are few and low-paid jobs. This article generated over 1,000 comments and the newspaper invited its readers to submit posters with suggestions of what negative aspects of life in Great Britain should be included in the campaign. A day later, the Guardian (Walsh et al., 2013) published an article coauthored with the newspaper's readers with a selection of what it considered were the best posters: some highlighted the bad weather (rain, grey sky), others the trash on the streets, while others referred to the politicians as not being representative or invoked the GREAT campaign (“government isn't GREAT Britain”).

The wider political background is that on January 1, 2014, all EU member states had to lift restrictions to their labor market for Romanians and Bulgarians who could fully exercise their right to work in all EU countries without a work permit. During the year prior to this measure coming into force, the topic of migration in Britain was recurrent subject of debates and heavily used in the nationalist discourses of the United Kingdom Independence Party (UKIP), that has basically portrayed the migrants as invaders and a threat to the UK. Romanians and Bulgarians migrants were particularly targeted by such discourses given that the countries were the last EU members at that time (Beciu \& Lazar, 2016). Even after January 2014, when the actual number of Romanian and Bulgarian migrants did not increase in the UK, the topic of migration remained on the British public agenda and ultimately became a central part of the campaign for the 2015 Brexit referendum.

The Romanian context. After Romania became a member of the European Union in 2007, the migration of Romanians reached a mass phenomenon: currently $17 \%$ of the population lives abroad (UN Department of Economic and Social Affairs, Population Division, 2016). This triggered other recurrent debates in Romanian society with regards to the economic, social and political consequences of this phenomenon. Moreover, the Romanian media often linked the coverage of Romanian migrants with the impact of their positive or negative actions on Romania's image:

A series of categories are thus legitimised, such as the migrants who have stood out in the destination countries through positive behaviour and actions ('the heroes'), recognised by the local communities. This category is counterposed to the migrants (1) who, in a way or 
another, have fallen victim to untoward events or (2) who were involved in crime, and (3)

to 'us', the Romanians who have remained in place. (Beciu \& Lazar, 2016, p. 53)

In the debates about the lifting of labor restrictions for Romanians and Bulgarians starting with 2014, the Romanian media covered extensively the British media: "the newspapers in Romania legitimise the idea of a dominant discourse in the UK that talked about an imminent 'invasion' or 'siege' of the British territory by the 'masses' or 'hordes' of Romanians, 'the immigrants of poverty" (Beciu \& Lazar, 2016, p. 58). Thus, the idea of Romania being placed in "an inferior" position (as country of origin for these "immigrants of poverty") in relations to the British partner (as wealthy receiving country) was again intensely used. This is an illustrative example of how these two major public issues in post-communist Romania (the negative image of the country and the high number of migrants) have been constantly re-enforcing each other and strategically used by political actors, state institutions and even media as arguments to legitimize different positions, initiatives or decisions.

At the same time, during the last years, in Romania there has been also an emergence of non-state actors engaging in promoting Romania through direct or indirect initiatives or campaigns that generate alternative discourses about the country: they have diversified the symbolic construction of Romania and Romanians that till 2010 had been dominated by the official government sponsored initiatives and discourses. Such an initiative is also the campaign "Why don't you come over" carried out by the communication group GMP (GMP Advertising, GMP PR and its digital agency Webstyler) for the Romanian newspaper Gandul.

\section{The "Why Don't You Come Over?" Campaign}

GMP Advertising and the online newspaper gandul.info launched the campaign on January 29, 2013, in 24 hours after the Guardian published the posters and images from its readers. The overall creative concept was to directly respond to the British campaign "You won't like it here" with the reverse "We might not like Britain, but you will love Romania. Why don't you come over?" According to the agency, the campaign aimed to fight discrimination with humor and build on Romania's defining trait, the hospitality: "by creating engaging content for gandul.info that would also energize the friends and relatives back home of those who live in the UK or planned to go there as honest tax payers" (GMP, 2015, p. 2). Therefore, they strategically "looked for topics that would generate buzz for both the Romanian and British audience. From the price of beer to the Middleton sisters" (GMP, 2015, p. 3). 


\section{Insert the image titled WDYCO colaj here}

The campaign started with posters appearing on the newspaper's Facebook page (Facebook.com/gandul.info) and the strategy to turn them into "viral posts" worked: "over 300.000 users had seen or commented or shared the posters on Facebook in the first 24 hours after posting, according to our data" said Mihai Gongu, Creative Director, GMP Advertising (Pantus, 2013). The Romanian media also contributed to this momentum: they had covered extensively on TV, radio and online the articles issued by the Guardian with regards to a possible governmental campaign to limit Romanian and Bulgarian immigrants in the UK. Consequently, given the sensitivity of the topic for Romanians and the great interest of how Romanians are perceived abroad, it was no surprise that Romanians engaged in this campaign.

Moreover, following the high rate of responses and the numerous comments from users who suggested other messages in response to the British campaign, the agency developed a Facebook App to allow users to generate their own posters, using a similar template. This led to the creation of 173 times more user generated posters than the original ones (GMP, 2015) which amplified the campaign, as each user also shared his/ her poster in his/her own network of friends.

The next step of the campaign was the creation of a couch-surfing website by Webstyler agency: whydontyoucomeover.co.uk (currently hosted at whydontyoucomeover.gandul.info), was conceived as a virtual place where the British could find free couches and jobs offered by Romanians. Over 300 couches and some dozen jobs were listed, a result considered successful by the GMP agency, due to the fact that couch-surfing is almost completely unknown in Romania (2015).

The media campaign also included a strategy of mixing posters with editorial content, therefore on the same page there was a poster of the campaign and an article on the same topic authored by a journalist. For instance, next to the poster that contained references to Prince Charles ("Charles bought a house here in 2005. And Harry has not been photographed naked once") there was an article about the village in Transylvania where Charles had his house. 
"Why don't you come over?" campaign concluded with an advertorial published on page 8 in The Guardian's edition from February 11, 2013: a letter addressed to David Cameron, the British Prime Minister, by gandul.info on behalf of the citizens ("thousands of Romanians and quite a few British citizens, too"). The letter aimed to invite politicians to "join" the talk between the people of the two countries.

All these online posters, Facebook app, couch-surfing website, and the advertorial formed ultimately a complex communication platform around a creative concept that invited people to a co-storytelling of who they are. Thus, the campaign managed to become a public diplomacy campaign with a high rate of discursive engagement, because it included all the three levels of engagement: (1) the posters generated initially a dynamic dialogic process with Romanians both at home and abroad, who not only liked the posters, but also commented and shared them, thus creating interaction (2); adding the app, the people were given a "voice" to co-create alternative discourses about themselves and about the country in which they live. These discourses complemented the official posters of the campaign.

\section{Insert the image titled WDYCO board here}

It was this cascading engagement process that attracted the attention of international media. Press agencies such as Reuters and Associated Press covered the campaign and over 100 articles were published in almost all Romanian media (TV, print, online) and in publications across the globe: Der Spiegel in Germany, El Pais and El Mundo in Spain, Le Figaro in France, Boston.com, The Washington Post and ABC News in US. According to the agency, it is the first Romanian ad campaign to date to be featured in an editorial in the prestigious TIME Magazine (GMP, 2015). In UK, the coverage included Financial Times, The Economist and BBC News, but also The Independent, Daily Mirror or Channel 4.

Besides its impact in social media and in online media, the "Why don't you come over?" campaign produced multiplication communication effects offline: a Romanian media company offered free outdoor advertisement (posters displayed in 10 premium bus-shelters and some of the most important hotels in central Bucharest, for 1 month); an English pub owner in the Old Centre of Bucharest offered to host the official posters on its walls, for free, for their British 
customers to enjoy; Romanian students in UK requested T-shirts with the campaign; The Daily Mirror sent journalists to Bucharest to verify the claims of the posters; Mr. Keith Vaz (Labour MP, Chairman of The Home Affairs Committee regarding Immigration) mentioned the campaign in the British Parliament (during the hearings about immigration from Romania and Bulgaria), came to Bucharest to discuss with Romanian authorities and wore the T-shirt of the campaign.

The campaign also managed to increase: (1) the advertising costs on the website and Facebook page of gandul.info, during and after the campaign by 160\%; (2) readership on gandul.info by $800 \%$, as well as the number of likes (over 250\%), shares (over 650\%) and Facebook engagement (the number of people "talking about this" / total number of page likes $120 \%$ ), compared to the period before the campaign (GMP, 2015). Commenting on the success of the campaign, the representatives of GMP Advertising and Webstyler pointed out as main elements: the rapid reaction ( 2 days between the Guardian posters and the gandul.info's posters), the excellent client - agency collaboration illustrated by the mix between the posters and the editorial content, as well as the favorable context of a public issue of interest for the Romanian society that made the campaign "develop naturally", thus being a huge publicity opportunity for the newspaper (Pantus, 2013).

\section{Applying CDA to the Campaign}

The critical discourse analysis of the campaign's posters ${ }^{i}$ focuses on elements such as: the actors granted visibility in this campaign; the status assumed by the actors; the relations of power between these actors; the symbols mobilized in the messages on the posters; as well as the overall discursive strategy employed.

At first sight, this is a campaign of a newspaper in response to another newspaper, in which readers are indirect actors who legitimize their initiatives. At a closer look, the collective actor constructed is the very people of Romania who respond to the people of Great Britain, which reveal two newspapers that assume a representative role for the "voice of their people". Furthermore, it is a campaign in which two nations with different power status (one attractive that receives people and another less attractive that sends people away) engage in dialogue.

The creative concept builds on an overall discursive strategy of difference between "we"/ "ours" (the Romanians) and "you"/"your" (the British), as well as "here" (in Romania) and "there" (in the UK). The direct interpellation in the slogan "We might not like Britain, but you will love Romania. Why don't you come over?" actually reverses the power relation between the 
sending and the receiving country: it places the Romanians in a more powerful position (the ones who make the invitation) towards the British who need to answer it. Moreover, the ones inviting are sure about the superiority status of their country ("you will love Romania"), thus the British need to reposition in the relationship between the two countries.

Symbolically, this slogan is very powerful to the Romanian audience and mobilizes not only a sensitive public issue (the negative image of Romania abroad), but also the "inferiority complex" of the Romanian society: this is a country that has begun very late its process of modernization, in the $19^{\text {th }}$ century, due to its geographical position between the Ottoman, Russian and Austro-Hungarian empires; a country that has constantly defined itself in relation with the neighboring countries. Therefore, this slogan captures and instrumentalizes these sensitive representations in the Romanian imaginary: it addresses a deep routed need of being superior by reversing the power balance between on old member of the European Union, a powerful European economy (the UK) and a new member of the EU, a weak European economy (Romania) that places its citizens in an inferiority position (of a migrant in search of a better life).

The discursive strategy of difference is implemented through simple short messages (no longer than 15 words) that strategically mobilize either key figures in British society (Kate Middleton, Prince Charles, Prince Harry) or aspects of ordinary life (weather, beer, food, level of English). The aim is to hyperbolize and show that in any aspect Romanians are simply better: "Our draft beer is less expensive than your bottled water"; "Half of our women look like Kate. The other half, like her sister". Irony is also used in the construction of messages: "Summer here last three months, not three hours"; "We speak better English than anywhere you've been in France"; "Our air traffic controllers have seen snow before. They are unimpressed").

The huge rate of non-state actor engagement, including all three levels of participation, interaction and co-creation with the internal publics of the campaign (the Romanians both within and outside the country), can be explained through the agile and strategic exploitation of: (1) different contexts (both from the past and recent history of Romania), (2) the different sensitive issues in society (the country image and the self representations of Romanians), (3) as well as the use of expert knowhow in managing integrated campaigns by a top communication agency in Romania. As pointed already, the campaign ultimately created a complex communication platform (Facebook app., website of couch and job offers), but more importantly it managed to 
co-create a public sphere where the voice of Romanians could be heard. Consequently, the posters created by Romanians using the Facebook app were statements about whom and how they are and what they have ("Our men are bigger than you Ben"; "Do you think you have the best black humor? Come and see Sapanta Cemetery"; "We have more English Pubs than Romanian Restaurants"). Ordinary citizens have been empowered to contribute to the definition of Romania. For a young democracy in which the 45 years of harsh Communism have left deep traces, this collective exercise of defining how Romanians are and what is specific for their identity is a way of collective catharsis and healing after an oppressive political system. That is why the exaggerations are present in almost all posters: they address this need of co-constructing the nation and its identity.

\section{Concluding Thoughts}

This chapter contributes to the overall discussion about communication engagement, illustrating how engagement has been conceptualized in public diplomacy literature. It has shown that engagement has emerged as a concept in public diplomacy in a turbulent global context that has led to a rethink of the practice and theory: the terrorist attacks from September 11, 2001. However, engagement was rather narrowly understood as a desired outcome of the public diplomacy process in which the states had the control over the environment and the overall communication process. It is starting with the articulation of the new public diplomacy (Melissen, 2005) and the interdisciplinary approaches to public diplomacy that engagement have come to be conceptualized as part of relationship building in a "people" to "people" communication process. Thus, it is possible to discuss about public diplomacy as being engagement of people to people on common or conflicting national and global interests (Gilboa, 2015).

Furthermore, this chapter takes a step forward and places the discussion on public diplomacy and engagement within a critical paradigm, to complement the dominant normative paradigm (how public diplomacy should be in order to engage people) or functional (how to improve the engagement of people). While these perspectives are useful particularly when it comes to the practice of public diplomacy, at theoretical level a critical paradigm has the merit of extending the common frames of reference, the possible angles of analysis, while providing 
explanations for a better understanding of this complex phenomenon. Reflecting on public diplomacy and engagement from a critical paradigm, the differences of status and power between actors and the very dynamics of the public diplomacy process are brought forward: it is possible to analyze engagement not only as an outcome, but also as discourses that are co-constructed by a variety of actors. This perspective is all the more important as state actors have lost the supremacy in public diplomacy and non-state actors have become more visible and willing to play a role in public diplomacy, on topics that were government's affairs only. In the current global context of support for anti-establishment trends, the rise of populism and nationalist parties and the reorganization of macro political structures (e.g. the unpredictable election of Trump, the successful Leave campaign for Brexit and consequently the rethink of the EU after Brexit), such perspectives become valuable for understanding the new reality, how alternative discourses are being produced and their impact in society.

The case study has illustrated how non-state actors (a communication group and an online newspaper) engage on a topic that is in itself a diplomatic one: the relations between two states that are members of a macro structure (EU) that regulates the access to the labor market. Symbolically, the two states have been replaced by the two newspapers (the Guardian and Gandul) who have mobilized specific internal contexts to construct platforms of engagement for their readers (public spheres), empower, and give them a voice on a matter of international politics that affects them directly. Furthermore, they co-created discourses about their country and themselves that reached the public agenda and had offline multiplication effects: what started as a Facebook campaign ended up being covered by the main TV, print and online Romanian media and gained extensive international coverage; other actors besides the communication group displayed the posters in bus-shelters, hotels or a pub; moreover, British journalists and politicians visited Romania.

The discussion on engagement and public diplomacy and the case study presented open other avenues of discussions and reflections for future studies, such as: (1) the role of media in the digital age. Media do not only mediate public diplomacy as before, but become actors in public diplomacy (with a distinct agenda, a certain power position and own discourses to be advanced); (2) the engagement of citizens in initiatives that are about themselves and their use of media platforms to bring forward alternative discourses about their national identity; 
(3) The decision of a communication group to embark in a campaign with almost no budget also brings several questions that invite for reflection: is this an action of a socially responsible actor that uses its know-how on a socially relevant topic to stand up for the people, replacing the state's role? Or is an action of an actor that manipulates a favorable context? And thus instrumentalizes a highly sensitive topic within a society on maters of national identity and self representations in order to obtain commercial gains for its client (e.g. increase readership)? What are the benefits and, yet, the limits of both perspectives?

(4) Another interesting aspect for further analysis is how a government might consider launching a negative campaign of self-representation targeted at specific countries, while it invests heavily in a global campaign such as Britain is GREAT. Is this a statement of power from a government that wants to select its future citizens/ residents/? Are such actions introducing discriminatory logics and symbolic discursive constructions of countries that are acceptable and countries that are not? And yet Great Britain, Romania and Bulgaria were part of the same macro structure - the European Union - where all members are equal, enjoy the same rights and liberties).

Above all, this chapter contributes to the understanding of public diplomacy as social practice that is influenced, negotiated through mutual interactions and interdependence between various state and non state actors and is ultimately co-constructed by them and even reconstructed over time. This socially centered and dynamic perspective of public diplomacy is extremely useful for practitioners in the current turbulent times: with the rise of populism, nationalism and extremism across the globe, it becomes essential to link public diplomacy more with global and local public issues relevant for societies and citizens and less with the international balance of power between states. In this model of people to people communication, conceptualizing public diplomacy as co-constructed discourses of engagement (including participation, interaction and co-creation) offers a sort of "democratized" vision of it (as opposed to the elitist vision of traditional public diplomacy): it acknowledges that people (demos) have also come to exert power (kratos) in public diplomacy. The new public diplomacy is no longer the formal power of the state actors that is legitimized by international treaties. It is a form of social power that has to consider marginalized and alternative discourses within societies that ultimately challenge, influence and co-construct the formal power of the state. 


\section{References}

Aronczyk, M. (2008). "Living the brand": Nationality, globality and the identity strategies of nation branding consultants. International Journal of Communication, 2, 41-65.

Beciu, C., \& Lazar, M. (2016). Instrumentalising the 'mobility argument': Discursive patterns in the Romanian media. In M. Endres, K. Manderscheid \& C. Mincke (Eds.), The mobilities paradigm discourses and ideologies (pp. 48-68). London \& New York: Routledge.

Castells, M. (2008). The new public sphere: Global civil society, communication networks, and global governance. The Annals of the American Academy of Political and Social Science, 616(1), 78-93.

Comor, E., \& Bean, H. (2012). America's “engagement” delusion critiquing a public diplomacy consensus. International Communication Gazette, 74(3), 203-220.

Cull, N. J. (2009). Public diplomacy: Lessons from the past. CPD Perspectives on Public Diplomacy. USC Center on Public Diplomacy, Los Angeles: Figueroa Press.

Der Derian, J. (2009). Critical practices in international theory. Selected essays. Abingdon, UK: Routledge.

Dolea, A. (2015a). The need for critical thinking in country promotion: public diplomacy, nation branding and public relations. In J. L'Etang, D. McKie, N. Snow \& J. Xifra (Eds.), The Routledge handbook of critical public relations (pp. 274-288). London \& New York: Routledge. Dolea, A. (2015b). Twenty years of (re)branding post-communist Romania. Actors, discourses, perspectives 1990-2010. Iasi: Editura Institutul European.

Drumheller, K., \& Benoit, W. L. (2004). USS Greeneville collides with Japan's Ehime Maru: Cultural issues in image repair discourse. Public Relations Review, 30, 177-185. 
Dutta-Bergman, M. (2006). U.S. public diplomacy in the Middle East: A critical cultural approach. Journal of Communication Inquiry, 30(2), 102-124.

Fairclough, N. (2001). Critical discourse analysis as a method in social scientific research. In R. Wodak \& M. Meyer (Eds.), Methods of critical discourse analysis (pp. 121-138). London: Sage Publications.

Fitzpatrick, K. (2007). Advancing the new public diplomacy: A public relations perspective. The Hague Journal of Diplomacy, 2(3), 187-211.

Fitzpatrick, K. R. (2010). The future of U.S. public diplomacy: An uncertain fate. Leiden: Brill.

Fuchs, C. (2014). Social media: A critical introduction. London: Sage.

Gilboa, E. (1998). Media diplomacy: Conceptual divergence and applications. International Journal of Press/ Politics, 3(3), 56-75.

Gilboa, E. (2016). Public diplomacy. In G. Mazzoleni (ed.) The International Encyclopedia of Political Communication, first edition (pp.1-9). New York: Wiley-Blackwell.

GMP (2015). Presentation of the campaign "Why don't you come over?” internal document.

Golan, G. (2013). An integrated approach to public diplomacy. American Behavioral Scientist 57(9), 1251-1255.

Gregory, B. (2015). Mapping boundaries in diplomacy's public dimension. The Hague journal of diplomacy, 11(1), 1-25.

Hayden, C. (2012). The rhetoric of soft power: Public diplomacy in global contexts. Lanham, MD: Lexington Books.

Hayden, C. (2013). Logics of narrative and networks in US public diplomacy: Communication power and US strategic engagement. The Journal of International Communication, 19(2), 196218. 
Heath, R., Toth, E., \& Waymer, D. (Eds.). (2009). Rhetorical and critical approaches to public relations II, second edition. New York: Routledge.

Henisz, W. (2014). Corporate diplomacy: Building reputations and relationships with external stakeholders. Sheffield, UK: Greenleaf.

Johnston, K. (2014). Public relations and engagement: Theoretical imperatives of a multidimensional concept. Journal of Public Relations Research, 26, 381-383.

Kaneva, N. (2009). Critical reflections on nation branding as discourse and practice. Paper presented at the International Conference Images of nations: Strategic Communication, Soft Power and the Media, Athens, Greece.

Kaneva, N. (2011). Nation branding in post-communist Europe: Identities, markets, and democracy. In N. Kaneva (Ed.), Branding post-communist nations. Marketizing national identities in the new Europe (pp. 3-22). New York, NY: Routledge.

Kent, M. L., \& Taylor, M. (2002). Toward a dialogic theory of public relations. Public Relations Review, 28, 21-37.

L'Etang, J. (2009). Public relations and diplomacy in a globalized world: An issue of public communication. American Behavioral Scientist, 53(4), 607-626.

Langhorne, R. (2005). The diplomacy of non-state actors. Diplomacy and Statecraft, 16, 331339.

Lord, K. N., \& Lynch, M. (2010). America's extended hand: Assessing the Obama Administration's global engagement policy. Washington, DC: Center for a New American Security.

Malone, G. (1985). Managing public diplomacy. Washington Quarterly, 8(3), 199-213. 
Mark, S. (2009). A greater role for cultural diplomacy. Netherlands Institute of International Relations "Clingendael". Discussion Papers in Diplomacy, 114. Retrieved from http://www.clingendael.nl/publications/diplomacy/papers/.

Melissen, J. (2005). The new public diplomacy: Between theory and practice. In J. Melissen (Ed.). The new public diplomacy. Soft power in international relations (pp. 3-27). New York, NY: Palgrave Macmillan.

Ordeix-Rigo, E., \& Duarte, J. (2009). From public diplomacy to corporate diplomacy: Increasing corporation's legitimacy and influence. American Behavioral Scientist, 53(4), 549-564.

Pamment, J. (2012). New public diplomacy in the 21st century: A comparative study of policy and practice. New York, NY: Routledge.

Pamment, J. (2014). Articulating influence: Toward a research agenda for interpreting the evaluation of soft power, public diplomacy and nation brands. Public Relations Review 40, 5059.

Pantus (February 21, 2013). Mihai Gongu si Bogdan Nitu comenteaza rezultatele si reactiile la campania Gandul „Why don't you come over?”. Iqads.ro, http://www.iqads.ro/articol/25151/mihai-gongu-si-bogdan-nitu-comenteaza-rezultatele-sireactiile-la-campania, accessed January 4, 2017.

Syal, R. (2013). Immigration: Romanian or Bulgarian? You won't like it here. The Guardian, https://www.theguardian.com/uk/2013/jan/27/uk-immigration-romania-bulgaria-ministers, accessed January $4^{\text {th }}, 2017$.

Snow, N. (2009). Rethinking public diplomacy. In N. Snow \& P. M. Taylor (Eds.), Routledge handbook of public diplomacy (pp. 3-11). London, UK: Routledge. 
Taylor, M., \& Kent, M. (2014). Dialogic engagement: Clarifying foundational concepts. Journal of Public Relations Research, 26, 384-398.

Tuch, H. (1990). Communicating with the world: US public diplomacy overseas. New York, NY: St. Martin's.

United Nations, Department of Economic and Social Affairs, Population Division (2016).

International Migration Report 2015: Highlights (ST/ESA/SER.A/375), http://www.un.org/en/development/desa/population/migration/publications/migrationreport/docs/ MigrationReport2015_Highlights.pdf, accessed January 4, 2017. van Dijk, T. A. (2001). Multidisciplinary CDA: A Plea for Diversity. In R. Wodak \& M. Meyer (Eds), Methods of critical discourse analysis (pp. 95-120). London, UK: Sage Publications.

Volcic, Z. (2008). Former Yugoslavia on the world wide web. Commercialization and branding of nation-states. The International Communication Gazette, 70(5), 395-413.

Walsh, J. \& Guardian readers (January 29, 2013). Putting people off coming to Britain: your pictures. The Guardian, https://www.theguardian.com/uk/gallery/2013/jan/29/immigrationbritain-ministers-gallery, accessed January $4^{\text {th }}, 2017$.

Wodak, R. (2001). What CDA is about - a summary of its history, important concepts and its developments. In R. Wodak \& M. Meyer (Eds), Methods of critical discourse analysis (pp. 113). London, UK: Sage Publications.

Wiseman, G. (2015). Isolate or engage: Adversarial states, US foreign policy, and public diplomacy. Stanford, CA: Stanford University Press.

Zaharna, R., Arsenault, A., \& Fisher, A. (Eds.). (2013). Relational, networked and collaborative approaches to public diplomacy: The connective mindshift. NewYork, NY: Routledge. 
${ }^{\mathrm{i}}$ All posters can be found http://whydontyoucomeover.gandul.info/, last accessed January 4, 2017. 